\title{
Factors of Personal Hygiene Habits and Scabies Symptoms at Islamic Boarding School
}

\author{
Shelvi Indah Ayu Puspita ${ }^{1)}$, Fatma Nur Ardiati ${ }^{1)}$, Retno Adriyani1) ${ }^{1}$, Neil Harris ${ }^{2)}$ \\ 1 Environmental Health Department, Faculty of Public Health, Universitas Airlangga, Surabaya, \\ Indonesia \\ 2 School of Medicine, Griffith University, Gold Coast Campus, Southport 4222, Australia \\ Corresponding directed to e-mail: retnoadriyani@fkm.unair.ac.id
}

\begin{abstract}
Background: Scabies is a contagious skin disease caused by mite Sarcoptes scabiei. The global incidence of scabies in 2014 was $0.3 \%-46 \%$, while the incidence of scabies in Indonesia, especially in Banyuwangi Regency was 1871 cases in 2016 and 1730 cases in 2017. Objective: The study objective was to determine the relationship between personal hygiene and symptoms of scabies among students. Methods: This study was an observational study with a cross-sectional design located at the Salafiyah Syafi'iyah Nurul Amin Islamic Boarding School, Kalipuro, Banyuwangi. The number of students living in Islamic boarding schools was 191 students, the sample size was 63 students by simple random sampling. Data regarding personal hygiene habits were collected in April-May 2020, it used Google Forms sent via WhatsApp application to the students and in-depth interviews with the student caregivers. Data analysis using chi-square test, presented in tables and narrative. Results: The results showed that $42.9 \%$ of students had symptoms of scabies and there was a significant relationship between personal hygiene and symptoms of scabies, especially in habit of scratching $(P$ value $=0.000)$ and the habit of using clothes, towels, as well as prayer tools together $(P$ value $=0.012)$. Conclusion: The habit of scratching body parts with nails and using clothes, towels and, prayer tools alternately could be risk factors for the transmission of scabies to students. Students should have good personal hygiene and not share their personal equipment such as clothes, towels, and, prayer tools. The boarding school managers were advised to complete sanitation facilities, to organize a clean and tidy bedroom competition between the students.
\end{abstract}

Keywords: Infectious diseases, Islamic boarding school, Sanitation, Sarcoptes scabiei, Scabies.

\section{INTRODUCTION}

The habit of maintaining personal hygiene is one of the efforts to prevent infectious diseases at the individual level to improve their health status (Afienna, 2018). These habits include the habit of washing hands using soap regularly, cleaning the body by bathing, brushing teeth, and wearing clean clothes (Ardiati, 2020). The poor habits of maintaining personal hygiene could induce a risk of developing dangerous and infectious diseases (Atikah, 2012).

Scabies is an infectious disease that attacks the skin tissue, especially in groups of people who have poor personal hygiene habits. This disease is known as scurvy with symptoms of itchy skin due to infection caused by the mite Sarcoptes scabiei (Akuta et al., 2021). The itching that occurs due to scabies is caused by an allergy to mites, mite eggs, and the sticking of dirt on the body (Waru, 2019). The skin of a person suffering from scabies appears reddish patches. Scabies is a disease whose transmission is carried through direct contact with patients, aside from that, the objects that have been contaminated by mites can also transmit scabies disease (Wulandari, 2018; Chandler and Fuller, 2019). Morphologically, Sarcoptes scabei is a small mite, the female is $330-450 \times 250$ $350 \mu \mathrm{m}$ and the male is smaller in size 200- 240 x 150-200 $\mu \mathrm{m}$ (Ardianty, 2017).

Scabies is commonly found in tropical countries and is still a health problem that needs to be observed (Pratiwi, 2020; Engelman et al., 2019). According to International Alliance for the Control of Scabies (IACS), the number 
of world scabies cases in 2014 was $0.3 \%$ to $46 \%$ (International Alliance for the Control of Scabies, 2014). The prevalence of scabies in developing countries was considered high, it affected more children and adolescents than adults (Fanissa and Andriyani, 2020). School-age children and adolescents were the highest contributors to scabies disease with an incidence of $6-27 \%$ among the total general population (Ihtiaringtyas, Mulyaningsih and Umniyati, 2019). According to a study conducted in Kenya, it showed that there was a scabies prevalence of $8.3 \%$ in formal schools while the prevalence of scabies in Islamic based schools in Turkey was 61-62\% (Baidillah and Khoiriah, 2018; Kouotou et al., 2016).

The prevalence of scabies in East Java Province was at $8.21 \%$ in 2012 (Ardiati, 2020). According to data obtained from the Banyuwangi Health Office, the number of scabies cases in Banyuwangi Regency was still high. The Banyuwangi Health Office has found 1871 cases of scabies in 2016, while in 2017 there were 1730 cases of scabies (Dinas Kesehatan Kabupaten Banyuwangi, 2016; Dinas Kesehatan Kabupaten Banyuwangi, 2017). There has been a decrease in the prevalence of scabies every year, however, Banyuwangi Regency was still not completely free from scabies disease.

A high prevalence of scabies is found in places that were occupied by many people, including prisons, orphanages, and Islamic boarding school (Wulandari, 2018). Islamic boarding schools (also known as pesantren) are places to live and gather as well as places to get Islamic education (Muafidah, Santoso and Darmiah, 2017).

Study on the incidence of scabies at Al-Baqiyatushshalihat, Tanjung Jabung Barat in 2017 stated that as many as 42.1\% students still had poor skin hygiene, as many as $57.9 \%$ students of which also still had poor bed and bed linen hygiene, and as many as another $50 \%$ students still had poor hand and nail hygiene (Parman et al., 2017). A similar study which was also conducted in 2017 at the Darul Mukhlisin Islamic Boarding School, Kendari City stated that there was a significant relationship between the habit of maintaining personal hygiene and the incidence of scabies (Ridwan, Sahrudin and Ibrahim, 2017).

Another similar study was also conducted in 2017 at the Darul Ma'arif Islamic Boarding School, Sintang Regency which research results showed that the habit of maintaining personal hygiene had a significant relationship with the incidence of scabies $(P$ Value $=0.018 ; \mathrm{OR}$ $=3.106 ; 95 \% \mathrm{Cl}=1.296-7.441)$ (Juliansyah and Juliansyah, 2017). The study conducted in Bandung Regency Islamic Boarding School stated that there was a significant relationship between the incidence of scabies and the habit of maintaining individual hygiene which included the hygiene of clothes, skin, genitalia, toiletries, and beds (Majid, Astuti and Fitriyana, 2020). A more indepth study to determine the relationship between the incidence of scabies in Islamic Boarding School and the habit of maintaining personal hygiene was needed to be conducted. This study aimed to analyze the relationship between personal hygiene habits and scabies symptoms in students of Islamic Boarding School.

\section{METHOD}

This study was an observational study with a cross-sectional approach and was conducted at Salafiyah Syafi'iyah Nurul Amin Islamic Boarding School. This Islamic Boarding School was one of the Islamic Boarding Schools with the biggest contributor to scabies disease in Kalipuro Village, Kalipuro District, Banyuwangi Regency.

Data collection was carried out in April to May 2020, under the conditions of the COVID-19 pandemic. The study population was all students who lived in Salafiyah Syafi'iyah Nurul Amin Islamic Boarding School, Banyuwangi Regency, as many as 191 students. The sample size of the study was 63 samples obtained by using simple random sampling, consisted of 38 female students and 25 male students. The collected data were regarding characteristics, symptoms of scabies, and the habit of maintaining student personal hygiene. Data collection was carried out by using a questionnaire that was distributed through Google form sent via WhatsApp application to the selected students. The questionnaire 
used has been tested for content validity. In-depth interviews with the student caregivers were conducted online by telephone and offline through face-to-face contact without violating the applicable COVID-19 protocol rules. The purpose of the interview was to obtain information about the condition of sanitation facilities and the daily habits of students related to personal hygiene.

The dependent and independent variables in this study were the symptoms of scabies and the habit of maintaining personal hygiene of students at Islamic Boarding School. The data were analyzed descriptively and analytically using chi-square test with $\alpha=$ 0.05. The study protocol has gained approval from the Health Ethics Commission of Faculty of Public Health, Universitas Airlangga stated on the Ethics Certificate No.52/EA/KEPK/2020.

\section{RESULTS AND DISCUSSION}

Banyuwangi Regency has several Islamic Boarding School which is located in several sub-districts. Salafiyah Syafi'iyah Nurul Amin Islamic Boarding School is a boarding school located in Kalipuro Village, Kalipuro District, Banyuwangi Regency. Apart from providing education in the form of Islamic Boarding School, this boarding school also provides formal education from the Raudhatul Athfal (RA) level which equivalent to Kindergarten (TK), Madrasah Ibtidaiyah (MI) which equivalent to Elementary School (SD), Madrasah Tsanawiyah (MTs) which equivalent to Junior High School (SMP) and Madrasah Aliyah (MA) which equivalent to Senior High School (SMA) with a total number of 800 students.

The questions given to identify the symptoms of scabies experienced by students including itching in the folds of the hands, feet, elbows, and thighs, especially at night was presented in Table 1. According to Table 1, it was known that students at Salafiyah Syafi'iyah Nurul Amin Islamic Boarding School in Banyuwangi Regency who had symptoms of scabies were as many as 31 students $(49.21 \%)$.

\begin{tabular}{lcr} 
Table 1. Frequency & $\begin{array}{c}\text { Distribution } \\
\text { Scabies } \\
\text { Respondents }\end{array}$ & $\begin{array}{r}\text { of } \\
\text { in }\end{array}$ \\
$\begin{array}{l}\text { Scabies } \\
\text { Symptoms }\end{array}$ & $\mathrm{N}$ & $\%$ \\
\hline Yes & 31 & 49.21 \\
No & 32 & 50.79 \\
\hline Total & 63 & 100.00 \\
\hline
\end{tabular}

The majority of the students at Salafiyah Syafi'iyah Nurul Amin Islamic Boarding School experienced symptoms of itching in several parts of the body which were the main symptoms of scabies infestation. The main and most commonly found symptoms of scabies was itching at night or nocturnal pruritus (Mutiara and Syailindra, 2016).

Table 2 presented descriptive information about the characteristics of the students and the symptoms of scabies. The characteristics of the students studied included gender, age, and the level of education pursued. The relationship between characteristics and symptoms of scabies experienced by students was described descriptively because the result of the analysis which used statistical tests obtained insignificant results. Descriptively, according to gender, female students had a tendency to experience symptoms of scabies (52.63\%). According to age, students aged 17-25 years old had the tendency to experience symptoms of scabies (58.33\%). While according to education pursued at Salafiyah Syafi'iyah Nurul Amin Islamic Boarding School, students in Madrasah Ibtidaiyah (MA) had the tendency to experience symptoms of scabies $(58.33 \%)$.

Table 2. Cross Tabulation between Characteristics of Students and Symptoms of Scabies at Salafiyah Syafi'iyah Nurul Amin Islamic Boarding School, Kalipuro, Banyuwangi Regency, in 2020

\begin{tabular}{|c|c|c|c|c|c|c|}
\hline \multirow{3}{*}{$\begin{array}{c}\text { Student } \\
\text { Characteristics }\end{array}$} & \multicolumn{4}{|c|}{ Scabies Symptom } & \multirow{2}{*}{\multicolumn{2}{|c|}{ Total }} \\
\hline & \multicolumn{2}{|c|}{ Yes } & \multicolumn{2}{|c|}{ No } & & \\
\hline & $\mathrm{n}$ & $\%$ & $\mathrm{n}$ & $\%$ & $\mathrm{n}$ & $\%$ \\
\hline \multicolumn{7}{|l|}{ Gender } \\
\hline Male & 11 & 44.00 & 14 & 56.00 & 25 & 100 \\
\hline Female & 20 & 52.63 & 18 & 47.37 & 38 & 100 \\
\hline
\end{tabular}




\begin{tabular}{lcccccc}
\hline Age (years) & & & & & \\
\hline $12-16$ & 17 & 43.59 & 22 & 56.41 & 39 & 100 \\
$17-25$ & 14 & 58.33 & 10 & 41.67 & 24 & 100 \\
\hline Level of Education & & & & & & \\
\hline $\begin{array}{l}\text { Junior High } \\
\text { School (MTs) }\end{array}$ & 10 & 37.04 & 17 & 62.96 & 27 & 100 \\
$\quad \begin{array}{l}\text { Senior High } \\
\text { School (MA) }\end{array}$ & 21 & 58.33 & 15 & 41.67 & 36 & 100 \\
\hline Total & 31 & 49.21 & 32 & 50.79 & 63 & 100 \\
\hline
\end{tabular}

The majority of the students at Salafiyah Syafi'iyah Nurul Amin Islamic Boarding School who had the symptoms of scabies were female students. In line with the study conducted in 2016 at Qotrun Nada Islamic Boarding School, Cipayung Depok which stated that as many as $53.6 \%$ of the students who suffered from scabies were female students (Ibadurrahmi, Veronica and Nugrohowati, 2016). The results of other similar study stated that most of the students who suffered from scabies were female students (96.2\%) (Naftassa and Putri, 2018). It was in contrast to the results of other similar study which stated that most of the students who suffered from scabies were male students (57.81\%) (Sutejo, Rosyidi and Zaelany, 2017). Thus, male or female had the same chance to suffer from scabies (Ibadurrahmi, and Nugrohowati, 2016).

The most group of age that experienced the symptoms of scabies was in the age group of 17-25 years. Age group $\leq 25$ years was classified as a young age which generally a person at a young age has a limited mindset and lack of experience, thus compared to those at mature age would have more sufficient mindset and experience in preventing the incidence of scabies (Imartha, Wulan and Saftarina, 2017).

In this study, the students who had symptoms of scabies were at Senior High
School (MA) education level. It was in contrast to the results of the study conducted in 2018 which stated that those at senior high school education level would most likely have lower risk to suffer scabies compared to those at junior high school education level (MTs) (Naftassa and Putri, 2018). In general, those with a high education level had a low risk of suffering infectious diseases, thus could minimize the incidence of infectious diseases (Anindya, 2018). The habit of maintaining personal hygiene is the most important thing in achieving one's physical and psychological wellbeing (Prayogi and Kurniawan, 2016).

The results of the study on the relationship between the habits of maintaining personal hygiene of students with symptoms of scabies experienced by students were presented in Table 3 . The habits of maintaining personal hygiene studied were the habit of bathing twice a day, cutting nails, washing hands, scratching the itchy body parts with fingernails, changing clothes every time taking shower, washing clothes with detergent, using shared bedding, wearing clothes, towels, and prayer tools, hanging dirty clothes in the same place as friend's clothes, and drying towels also bedding (bolsters, pillows, mattresses).

Table 3. Cross Tabulation between the Habit of Maintaining Personal Hygiene and the Symptoms of Scabies of the Students at Salafiyah Syafi'iyah Nurul Amin Islamic Boarding School, Kalipuro, Banyuwangi Regency, in 2020

\begin{tabular}{|c|c|c|c|c|c|c|c|}
\hline \multirow{3}{*}{$\begin{array}{l}\text { The Habits of } \\
\text { Maintaining } \\
\text { Personal Hygiene }\end{array}$} & \multicolumn{4}{|c|}{ Scabies Symptoms } & \multirow{2}{*}{\multicolumn{2}{|c|}{ Total }} & \multirow{3}{*}{$\begin{array}{c}P \\
\text { Value }\end{array}$} \\
\hline & \multicolumn{2}{|c|}{ Yes } & \multicolumn{2}{|c|}{ No } & & & \\
\hline & $n$ & $\%$ & $n$ & $\%$ & $\mathbf{N}$ & $\%$ & \\
\hline \multicolumn{8}{|l|}{ Bathing } \\
\hline Yes & 29 & 51.79 & 27 & 48.21 & 56 & 88.89 & \multirow{2}{*}{0.426} \\
\hline No & 2 & 28.57 & 5 & 71.43 & 7 & 11.11 & \\
\hline \multicolumn{8}{|l|}{ Cutting Nails } \\
\hline Yes & 25 & 46.29 & 29 & 53.71 & 54 & 85.71 & \multirow{2}{*}{0.302} \\
\hline No & 6 & 66.67 & 3 & 33.33 & 9 & 14.29 & \\
\hline Washing Hand & & & & & & & \\
\hline
\end{tabular}




\begin{tabular}{|c|c|c|c|c|c|c|c|}
\hline $\begin{array}{l}\text { Yes } \\
\text { No }\end{array}$ & $\begin{array}{r}31 \\
0\end{array}$ & $\begin{array}{r}51.67 \\
0.00\end{array}$ & $\begin{array}{r}29 \\
3\end{array}$ & $\begin{array}{r}48.33 \\
100.00\end{array}$ & $\begin{array}{r}60 \\
3\end{array}$ & $\begin{array}{r}95.24 \\
4.76\end{array}$ & 0.238 \\
\hline \multicolumn{8}{|c|}{ Scratching } \\
\hline Yes & 30 & 65.22 & 16 & 34.78 & 46 & 73.02 & \multirow{2}{*}{0.000} \\
\hline No & 1 & 5.88 & 16 & 94.12 & 17 & 27.08 & \\
\hline \multicolumn{8}{|c|}{ Changing Clothes } \\
\hline Yes & 22 & 45.83 & 26 & 54.17 & 48 & 76.19 & \multirow{2}{*}{0.338} \\
\hline No & 9 & 60.00 & 6 & 40.00 & 15 & 23.81 & \\
\hline \multicolumn{8}{|c|}{ Washing Clothes } \\
\hline Yes & 29 & 48.33 & 31 & 51.77 & 60 & 95.24 & \multirow{2}{*}{0.613} \\
\hline No & 2 & 66.67 & 1 & 33.33 & 3 & 4.76 & \\
\hline \multicolumn{8}{|c|}{ Using Shared Bedding } \\
\hline Yes & 27 & 47.37 & 30 & 52.63 & 57 & 90.47 & \multirow{2}{*}{0.426} \\
\hline No & 4 & 66.67 & 2 & 33.33 & 6 & 9.53 & \\
\hline \multicolumn{8}{|c|}{ Wearing Shared Clothes, Towels, and Prayer Tools } \\
\hline Yes & 29 & 56.86 & 22 & 43.14 & 51 & 80.95 & \multirow[b]{2}{*}{0.012} \\
\hline No & 2 & 16.67 & 10 & 83.33 & 12 & 19.05 & \\
\hline \multicolumn{8}{|c|}{ Hanging Dirty Clothes } \\
\hline Yes & 12 & 60.00 & 8 & 40.00 & 20 & 31.75 & \multirow{2}{*}{0.243} \\
\hline No & 19 & 44.19 & 24 & 55.8 & 43 & 68.25 & \\
\hline \multicolumn{8}{|c|}{ Drying Towels and Bedding } \\
\hline Yes & 18 & 45.00 & 22 & 55.00 & 40 & 63.49 & \multirow[b]{2}{*}{0.378} \\
\hline No & 13 & 56.52 & 10 & 43.48 & 23 & 36.51 & \\
\hline Total & 31 & 49.21 & 32 & 50.79 & 63 & 100.00 & \\
\hline
\end{tabular}

According to data presented in Table 3, the habits of the students in maintaining personal hygiene that had to be kept including washing hand (95.24\%), washing clothes with detergent (95.24\%), bathing twice a day (88.89\%), and cutting nails $(85.71 \%)$. Meanwhile, the habits that had to be improved including changing clothes every time taking shower (76.19\%), not hanging dirty clothes in the same place as friend's clothes (68.25\%), also drying towels, mattresses, pillows, and bolsters (63.49\%).

The habits of maintaining personal hygiene including using shared bedding (90.47\%), wearing shared clothes, towels, and prayers tools $(80.95 \%)$, and scratching with fingernails $(73.02 \%)$ needed to get more attention to prevent in becoming the disease transmission medium, especially scabies. The habits of maintaining the personal hygiene of students that had a significant relationship with scabies symptoms were the habit of scratching with fingernails $(P$ Value $=0.000$ ), and the habit of wearing shared clothes, towels, also prayer tools $(P$ Value $=0.012)$.

The habit of maintaining personal hygiene in this case including bathing regularly at least twice a day was needed to be maintained by the students at Salafiyah Syafi'iyah Nurul Amin Islamic Boarding School in Banyuwangi Regency. The majority of the students have routinely bathed twice a day. This is a good habit of maintaining personal hygiene. In this study, the habit of bathing twice a day was not included as a significant risk factor of developing scabies. Bathing is one of the human needs on hygiene to maintain a healthy body. Bathing with soap helps to maintain body hygiene and skin health. The skin is the front line of protection for the body from various dirt, germs, and diseases, including the scabies mite.

Hygiene of hands and nails, namely the habit of cutting nails and washing hands also did not show a significant relationship to scabies symptoms in students at Salafiyah Syafi'iyah Nurul Amin Islamic Boarding School in Banyuwangi Regency. The students have paid close attention to the hygiene of their hands and nails. Hands are the part of the body that most often interacts or form contact with objects around humans.

Unhygienic hands can be a place for various germs and dirt to stick. This was in line with the other similar study which stated that a person who did not maintain good hygiene, especially in terms of hand and nail hygiene, would have a 3.473 times greater chance of suffering scabies compared to those who was able to maintain the hygiene of hands and nails (Parman et al., 2017). Even though in plain sight the hands looked clean, it did not guarantee that the hands were clean from germs and dirt. Germs 
and dirt could stick under the nails. Long, dirty, and uncut nails could increase the risk of developing skin diseases ( $T$ Carolyne, 2020). Thus, the habit of washing hands and cutting nails must be done regularly to keep the hygiene of the hands and to prevent the risk of developing scabies.

The variable of scratching with nails showed a significant relationship to the onset of scabies symptoms. Sarcoptes scabiei mites could easily stick to the parts of the body of those who could not maintain good hygiene of their body and could easily spread to the other parts of the body if the patient had a habit of scratching the lesion or the itchy body parts. This could give easier access to the Sarcoptes scabiei mites to move from the nails to other body parts (Affandi, 2019).

In a study that observed the nails of the respondents, some of them were reported positive for having Sarcoptes scabiei mites on their nails (Nurohmah, 2018). A person was expected to have an awareness of the importance of maintaining personal health, one of which was through maintaining body hygiene such as took care of the hygiene of skin, hands, nails, clothes, towels, as well as the hygiene of the used bed linen (Prayogi and Kurniawan, 2016). Therefore, maintaining the hygiene of hands is an important thing to do for every individual to prevent the risk of transmitting skin diseases such as scabies.

The habits of using shared clothes, towels, and prayers tools were also showed a significant relationship to the onset of scabies symptoms in students. One of the factors that caused the habit was the insufficient bathroom facilities at Salafiyah Syafi'iyah Nurul Amin Islamic Boarding School in Banyuwangi. The students could only use one shared bathroom for 2 to 3 students at a time. Ideally, one bathroom is used by one person even if used in turns. This condition also allowed the students to use the towels in turns.

A similar study also stated that toiletries such as towels, soap, and so on could be the place for the microorganisms that caused skin diseases to stick on its surface. The microorganism which stuck on the toiletries could be transferred to another person if used in turns (Andani, 2020). The use of shared towels could increase the risk to be infected by scabies disease from those who suffered scabies to healthy individuals because towels became the indirect contact means of scabies transmission (Darmiah, Muafidah and Santoso, 2017). The incidence of scabies could occur in those with a low socioeconomic status who tend to have insufficient sanitation facilities and infrastructure (Afriani, 2017).

The density of the bedroom occupancy and the use of the bed also need to be considered. The use of one bedroom space for several students increased the possibility of lending each other personal tools for shared use, for example lending each other prayer tools and clothes. Excessive occupancy density was one of the risk factors for scabies transmission (Kementerian Kesehatan Republik Indonesia, 2015). According to the results of a study conducted in 2016 which stated that students who had a poor habit of maintaining personal hygiene were more commonly found in Islamic boarding schools that did not have complete facilities $(87.8 \%)$ compared to the Islamic boarding schools that had complete facilities $(36.5 \%)$ (Zakiudin and Shaluhiyah, 2016). Sufficient facilities and infrastructure or boarding school facilities have an important role in supporting the activities to maintain the personal hygiene of the students. Efforts to improve the good habits of maintaining personal hygiene, especially among students at Salafiyah Syafi'iyah Nurul Amin Islamic Boarding School in Banyuwangi needed to be improved.

The habit of using shared bedding did not show a significant relationship to the onset of scabies symptoms in students. In line with the results of the study conducted in 2019 at Guidance Institution Special for Children (also known as LPKA) which stated that there was no significant relationship between the use of shared blankets with the incidence of scabies (Ariningtyas, 2019). However, using the shared bedding such as pillows, bolsters, blankets, mats, carpets, and other bedding could lead to the transmission of scabies in students (Affandi, 2019).

The habits of maintaining personal hygiene related to the habits of changing clothes, washing the clothes with detergent, and hanging the dirty clothes at the same place as friend's clothes also did not show a significant 
relationship to the onset of scabies symptoms in students. Apart from the limitations of the Islamic boarding school in providing sufficient hygiene and sanitation facilities for each student, it will be better if the students have the habits of diligently washing the clothes that have been worn, separating dirty clothes from clean clothes to prevent the development of microorganisms that can grow easily in humid places, especially on clothes that have been worn.

The habit of drying towels, mattresses, pillows, and bolsters also did not have a significant relationship to the onset of scabies symptoms in students. The students at Salafiyah Syafi'iyah Nurul Amin Islamic Boarding School in Banyuwangi have gotten used to drying their bedding and towels under the sun. This can inhibit the proliferation of mites. Scabies mites were known to survive better in humid places. The more humid the place was, the longer the scabies mites would be able to survive (Naftassa and Putri, 2018). The sunlight will reduce the humidity of towels, mattresses, pillows, and bolsters, as well as kill the scabies mites. These habits must be maintained. Maintaining personal hygiene is one of the prevention efforts in minimizing the occurrence of skin diseases (Marga, 2020) as well as one of the forms of protection for the body to fight germs that could cause skin infections (Nikmah and Widyasih, 2018).

\section{CONCLUSION}

There was a significant relationship between the habits of maintaining personal hygiene with symptoms of scabies, especially in the habits of scratching body parts and wearing shared clothes, towels, and prayer tools. The habit of scratching body parts and wearing shared clothes, towels, and prayer tools simultaneously could increase the risk of transmitting scabies disease among students.

The students should improve better habits of maintaining personal hygiene. Manager of Salafiyah Syafi'iyah Nurul Amin Islamic Boarding School in Banyuwangi Regency could complement the facilities of the boarding school in accordance with applicable guidelines to create qualified human resources, hold hygiene competitions, and provide information through wall magazine with environmental-based topics on personal hygiene habits and skin diseases.

The next suggestion was to minimize two significantly related risks such as scratching with nails could be minimized by washing hands using soap after scratching itchy body parts knowing that the itchy body parts might contain mites that can cause scabies. As for the use of shared goods, the students should be able to get used to not borrowing or lending personal items to others to break the chain of transmission of scabies disease.

\section{ACKNOWLEDGEMENT}

The author would like to thank Mrs. Retno Adriyani ST., M.Kes as the supervisor of this article. Hopefully this scientific article can be a reference material and increase knowledge for readers.

\section{REFERENCES}

Affandi, A. A. N. (2019) 'Analisis Personal Hygiene dan Keberadaan Sarcoptes Scabiei di Debu Alas Tidur Warga Binaan Pemasyarakatan pada Kejadian Skabies di Lapas Kelas IIB Jombang', Jurnal Kesehatan Lingkungan, 11(3), p. DOI: $10.20473 / j k l . v 11 i 3.2019 .165-174$.

Afienna, H. (2018) 'Hubungan Personal Hygiene dan Sanitasi Lingkungan dengan Kejadian Penyakit Scabies di Pondok Pesantren Marifatul Ulum Bringin Kabupaten Ngawi', Skripsi, p. Tersedia di http://repository.stikesbhm.ac.id/335.

Afriani, B. (2017) 'Hubungan Personal Hygiene dan status Sosial Ekonomi dengan Kejadian Skabies di Pondok Pesantren', Jurnal IImu Kesehatan, 2 (1), 1-1, p. https://doi.org/10.30604/jika.v2i1.25.

Akuta, T. et al. (2021) 'Development of A Rapid Scabies Immunodiagnostic Assay Based on Transcriptomic Analysis of Sarcoptes Scabiei Var. Nyctereutis', Scientific Reports, 11(6455), p. Doi: https://doi.org/10.1038/s41598-02185290-7.

Andani, M. (2020) 'Hubungan Perilaku dan Kepadatan Hunian dengan Penyakit Skabies pada Warga Binaan Permasyarakatan di Rutan Kelas II B Menggala Tahun 2020', Diploma Tesis, 
p.

di:http://repository.poltekkes-

tjk.ac.id/.

Anindya, S. R. (2018) 'Hubungan Kondisi Lingkungan Fisik dan Perilaku Hidup Bersih dan Sehat dengan Kejadian Scabies di Lembaga Pemasyarakatan Kelas IIA Jember', Skripsi, p. Tersedia di:https://repository.unej.ac.id/bitstr ea.

Ardianty, S. (2017) 'Hubungan Pengetahuan dan Sikap Personal Hygiene dengan Kejadian Skabies di SD Negeri 2 Panggung Harjo Kecamatan Air Sugihan Kabupaten Ogan Komering Ilir Sumatera Selatan.', Medika Cendikia, Vol.4 No.2, p. Tersedia di:http://www.jurnalskhg.ac.id/index. $\mathrm{php} /$.

Ardiati, F. N. (2020) 'Hubungan Higiene Personal dan Karakteristik Santri dengan Gejala Scabies di Pondok Pesantren (Studi di Pondok Pesantren Salafiyah Sayfi'iyah Nurul Amin Kalipuro Banyuwangi)', Skripsi. Program Studi Kesehatan Masyarakat. Universitas Airlangga.

Ariningtyas, D. N. (2019) 'Analisis Karakteristik dan Higiene Individu dengan Kejadian Skabies di Lembaga Pembinaan Khusus Anak (LPKA) Kelas I Blitar', Jurnal Keperawatan Muhammadiyah, (Edisi Khusus), pp. 225-231.

Atikah, D. (2012) 'Perilaku Hidup Bersih dan Sehat (PHBS)', Nuha Medika, Yogyakarta.

Baidillah and Khoiriah, N. (2018) 'Beberapa Faktor Risiko Penyakit Gudikan (Scabies) di Pondok Pesantren Binaul Ummah Desa Bawuran, Pleret, Bantul Tahun 2018', Jurnal Kesehatan dan Pengelolaan Lingkungan, 1(1), p. Tersedia http://journal2.uad.ac.id/index.php/j

Chandler, D. and Fuller, L. (2019) 'A Review of Scabies: An Infestation More Than Skin Deep.', Dermatology, 235(2), pp. 79-90.

Darmiah, Muafidah, N. and Santoso, I. (2017) 'Hubungan Personal Higiene dengan Kejadian Skabies pada Santri Pondok Pesantren Al Falah Putera Kecamatan Liang Anggang Tahun 2016', Journal of Health Science and Prevention, 1(1), p. Doi: https://doi.org/10.29080/jhsp.v1i1.5.

'Dinas Kesehatan Kabupaten Banyuwangi'
(2016) Data Penyakit Menular dan Penyakit Tidak Menular.

'Dinas Kesehatan Kabupaten Banyuwangi' (2017) Data Penyakit Menular dan Penyakit Tidak Menular.

Engelman, D. et al. (2019) 'The Public Health Control of Scabies: Priorities for Research and Action.', Lancet, 394(10192), pp. 81-92.

Fanissa and Andriyani, Y. (2020) 'The Correlation of Santri's Personal Hygiene to the Incidences of Scabies in Pesantren Al-Kautsar Simalungun (a boarding school).', Journal of Endocrinology, Tropical Medicine, and Infectiouse Disease, p. https://doi.org/10.32734/jetromi.v2i1 .3494. doi: 10.32734/jetromi.v2i1.3494.

Ibadurrahmi, H., Veronica, S. and Nugrohowati, N. (2016) 'Faktor-Faktor yang Berpengaruh terhadap Kejadian Penyakit Skabies pada Santri di Pondok Pesantren Qotrun Nada Cipayung Depok Februari Tahun 2016', Jurnal Profesi Medika, 10(1), p. DOI: http://dx.doi.org/10.33533/jpm.v10i1 .12.

Ihtiaringtyas, S., Mulyaningsih, B. and Umniyati, S. R. (2019) 'Risk Factor of Scabies on Students of An Nawawi Islamic Boarding School in Berjan Gebang Subdistrict Purworejo District of Central Java', BALABA, 15(1), p. DOI:

https://doi.org/10.22435/blb.v15i1.17 84.

Imartha, A. G., Wulan, A. J. and Saftarina, F. (2017) 'Faktor-Faktor yang Berhubungan dengan Kejadian Skabies di Pondok Pesantren Jabal AnNur Al-Islami Kecamatan Teluk Betung Barat Kota Bandar Lampung', Medula, 7(5), p. Tersedia di: juke.kedokteran.unila.ac.id.

International Alliance for the Control of Scabies (2014) Skabies.

Juliansyah, E. and Juliansyah, L. A. M. E. (2017) 'Jenis Kelamin, Personal hygiene, dan Sanitasi Lingkungan dengan Kejadian Penyakit Scabies Pada Santri di Pondok Pesantren Darul Ma'arif Kabupaten Sintang', JUMANTIK: Jurnal Mahasiswa dan Peneliti Kesehatan, Vol.4 No.1, p. https://doi.org/http://dx.doi.org/10. 29406/jjum.v4. doi: http://dx.doi.org/10.29406/jjum.v4i1. 844. 
Kemenkes (2015) 'Panduan Praktik Klinis bagi Dokter di Fasilitas Pelayanan Kesehatan Tingkat Pertama'.

Kouotou, E. A. K. et al. (2016) 'Prevalence and Drivers of Human Scabies Among Children and Adolescents Living and Studying in Cameroonian Boarding Schools', BMC: Parasites \& Vectors, 9(1), p. Tersedia di:

http://parasitesandvectors.biomedcen t.

Majid, R., Astuti, R. D. I. and Fitriyana, S. (2020) 'Hubungan Personal Hygiene dengan Kejadian Skabies pada Santri di Pesantren Kabupaten Bandung Tahun 2019', Jurnal Integrasi Kesehatan dan Sains, 2(2), p. DOI: https://doi.org/10.29313/jiks.v2i2.559 0.

Marga, M. P. (2020) 'Pengaruh Personal Hygiene Terhadap Kejadian Penyakit Skabies', Jurnal IImiah Kesehatan Sandi Husada, 9(2), p. DOI: https://doi.org/10.35816/jiskh.v12i2.4 02.

Muafidah, N., Santoso, I. and Darmiah (2017) 'The Relation of Personal Hygiene with The Incidence of Scabies at Al Falah Male Boarding School Students Sub-district of Liang Anggang in the Year 2016', Journal of Health Science and Prevention, 1(1), p. Tersedia

di:http://jurnalfpk.uinsby.ac.id/index .ph.

Mutiara, H. and Syailindra, F. (2016) 'Skabies', Medical Journal of Lampung University, 5(2), p. Tersedia di: https://juke.kedokteran.unila.ac.id/i.

Naftassa, Z. and Putri, T. R. (2018) 'Hubungan Jenis Kelamin, Tingkat Pendidikan dan Pengetahuan Terhadap Kejadian Skabies pada Santri Pondok Pesantren Qotrun Nada Kota Depok', Biomedika, 10(2), p. DOI: https://doi.org/10.23917/biomedika.v 10i2.7022.

Nikmah, U. S. and Widyasih, H. (2018) 'Personal Hygienen Habits dan Kejadian Flour Albus Patologis pada Santriwati PP AL-Munawwir, Yogyakarta.', Jurnal Media Kesehatan Masyarakat Indonesia:The Indonesian Journal of Public Health., Vol. 14 No, p. $\quad$ DOI : http://dx.doi.org/10.30597/mkmi.v14i 1.3714.

Nurohmah, P. I. (2018) 'Kondisi Fisik
Lingkungan dan Keberadaan Sarcoptes Scabiei pada Kuku Warga Binaan Pemasyarakatan Penderita Skabies di Blok A Lembaga Pemasyarakatan Kelas I Surabaya', Jurnal Kesehatan Lingkungan, VOL.10, N, p. Tersedia di: https://e-journal.unair.ac.id/JKL/art.

Parman et al. (2017) 'Faktor Risiko Hygiene Perorangan Santri Terhadap Kejadian Penyakit Kulit Skabies di Pesantren Al- Baqiyatushshalihat Tanjung Jabung Barat Tahun 2017', Jurnal Ilmiah Universitas Batanghari Jambi, 17(3), p. DOI: http://dx.doi.org/10.33087/jiubj.v17i 3.418 .

Pratiwi, U. (2020) 'Faktor yang Berhubungan dengan Kejadian Scabies pada Santri Perempuan di Pondok Pesantren Abdur Rohman Kabupaten Lahat', Skripsi, p. Tersedia di:https:// repository.unsri.ac.id/3509 $8 / 3$.

Prayogi, S. and Kurniawan, B. (2016) 'Pengaruh Personal Hygiene dalam Pencegahan Penyakit Skabies.', Medical Journal of Lampung University, 5(5), p. Persedia di:http://juke.kedokteran.unila.ac.id/ ind.

Ridwan, A. R., Sahrudin, S. and Ibrahim, K. (2017) 'Hubungan Pengetahuan, Personal hygiene, dan Kepadatan Hunian dengan Gejala Penyakit Skabies pada Santri di Pondok Pesantren Darul Muklisin Kota Kendari 2017', Jurnal IIm Mhs Kesehat Masyarakat, 2017;2(6), p. Tersedia di http://ojs.uho.ac.id/index.php/JIMKE SM.

Sutejo, I. R., Rosyidi, V. A. and Zaelany, A. I. (2017) 'Prevalensi, Karakteristik dan Faktor-faktor yang Berhubungandengan Penyakit Skabies di Pesantren Nurul Qarnain Kabupaten Jember', e-Jurnal Pustaka Kesehatan, 5(1), p. Tersedia di: http://jurnal.unej.ac.id/index.php/JP

T Carolyne, R. N. (2020) 'Analisis FaktorFaktor yang Memengaruhi Kejadian Skabies di Lembaga Pembinaan Khusus Anak (LPKA) Kelas II Kota Pekanbaru Tahun 2019', Tesis, p. Tersedia di:http://repositori.usu.ac.id/bitstrea $\mathrm{m} /$.

Waru, H. N. (2019) 'Studi Penggunaan Alat Pelindung Diri, Personal Hygiene dan Gejala Penyakit (Scabies) pada 
100 Jurnal Promkes: The Indonesian Journal of Health Promotion and Health Education Vol. 9 No. 2, September 2021, 91-100 doi: 10.20473/jpk.V9.12.2021.91-100

Pemulung di Tempat Pembuangan Akhir (TPA) Alak', Politeknik Kesehatan Kemenkes Kupas. Kesehatan Lingkungan., p. Tersedia di http://repository.poltekeskupang.ac.i d.

Wulandari, A. (2018) 'Hubungan Personal Hygiene dan Sanitasi Lingkugan dengan Kejadian Skabies pada Santri di Pesantren Ulumul Qur'an Kecamatan Bebesen Kabupaten Aceh Tengah.', Global Health Science., Vol.3 No.4, p. Tersedia

http://jurnal.csdforum.com/index.php /g.

Zakiudin, A. and Shaluhiyah, Z. (2016) 'Perilaku Kebersihan Diri (Personal Hygiene) Santri di Pondok Pesantren Wilayah Kabupaten Brebes akan Terwujud Jika Didukung dengan Ketersediaan Sarana Prasarana', Promosi Kesehatan Indonesia, Volume 11, https://doi.org/10.14710/jpki.11.2.64 -83 . 